\title{
Tackling Māori Masculinity: A Colonial \\ Genealogy of Savagery and Sport
}

Brendan Hokowhitu

\section{Contextualization}

In the nineteenth century Māori masculine physicality was, like the untamed countryside, something to be conquered and civilized; in the twentieth century it was something to be harnessed to provide manual labor for New Zealand's developing colonial nation; in the twenty-first century it has become a spectacle played out by the overachievement of tàne (Māori men) on the sports field. ${ }^{1}$ So how did a Māori boy, who once reveled in the physicality of rugby and other physical pursuits, and who has completed bachelor, master's, and doctoral degrees in physical education and sport, come to such conclusions?

As a youth, my passion for the physical was not dissimilar to that of many boys of my age who grew up in rural New Zealand. I was raised in a masculine culture where it was necessary for both Māori and Pākehā males to demonstrate their physical aptitude. ${ }^{2}$ In my hometown of Ōpōtiki, ${ }^{3}$ physical conquests, especially in sport, gave me confidence and allowed me to strive for success without facing ridicule. In contrast, academic achievement was at best acknowledged but usually derided. Males had to be extremely confident in their physicality or face social ostracism. So embroiled in this masculine culture was I, that I believed it defined all New Zealand men, both Māori and Pākehā. Looking back, however, I realize that while physicality was a common definer of New Zealand males, Mãori boys often faced barriers to the nonphysical realm that Pākehā boys did not.

A turning point in my life experiences occurred in 1985 when a university careers adviser visited my school. When I asked him about studying physical education at university, he replied, "PE is not for you. It involves 
biology, anatomy, physiology, and other scientific subjects; it's not just about running around and jumping." I walked away extremely despondent, unable to comprehend why I was being told I could not do PE. The adviser did not even know my name; he knew nothing about my academic record or my capabilities; all he knew was that I was Māori, wore an earring, and had long hair. He saw my interest in physical education as stemming from a lazy disposition. From his perspective, I was searching for an easy, nonacademic career-a career in the physical as opposed to the intellectual. Yet, even my self-limitation to a vocation in physical education points to the social constraints on which many young tane base their life decisions. Being a lawyer, a doctor, or an academic were not options I considered even plausible. I had the desire to succeed but ultimately only within the physical realm.

As a youth, I aspired to achieve in sport more than in any other area. My relationship with sport began with a bonding between son and father - particularly, a Māori father, who saw sport as an avenue to communicate with his son. My father, like many Māori of his generation, lived for sports. He grew up in an era when sport was one of the few spheres where tāne could achieve success and compete with Pākehā men on an "even playing field" and, accordingly, could gain mana in the Pākehā world. My father's enthusiasm for sport carried over to me, along with a definition of masculinity based on the noble, physically tough, staunch, and emotionless Māori men we witnessed on the local, provincial, and national rugby fields.

These beliefs were to change radically as my critical awareness grew. Ten years after leaving Ōpōtiki I found myself back at Ōpōtiki College, but this time as a semi-power holder-a physical education teacher. I had high hopes of providing students with a positive learning experience. But after only two years, I realized how futile my efforts were. The majority of Māori senior boys at Ōpōtiki College were, in United States terms, “jocks." They did little or no schoolwork, and, by turning a blind eye, the staff allowed them to hang out in the social room, play computer games, talk, and wait for PE or rugby or netball practice. While these students played sport at the highest level for their school—and in some cases for their province and country-teachers did not place academic demands on them. Moreover, younger Māori boys admired their elder peers and afforded them great status in the school.

My growing realization of how I and other tane had been constructed led to my doctoral research, which in large part focused on the genealog- 
ical construction of Māori as inherently physical. ${ }^{4}$ Yet, the self-emancipatory journey that was my $\mathrm{PhD}$ study and subsequently led me to enter academe has come at a double-edged cost. On the one hand, as a six-foottwo, 230-pound tāne, now a "white-collar" professional, I constantly had to (and continue to) confront the socially inculcated doctrines associated with being a physically large Māori man. Innumerable times colleagues have judged my intelligence based on my appearance. Recently, I applied for a prestigious, externally-funded, research grant. When I advanced to the second round (only four applications from my university advanced to this stage), colleagues outside my department received the news with a degree of surprise-which could only have been based on my physical appearance. I have had many similar experiences in which Pākehā academics have treated me with disdain and condescension, a number of them considering a Māori academic incongruous-an attitude similar to that of a current Dunedin City Councilor who recently surmised, "[I had] always thought a Maori working party was a contradiction in terms" (Otago Daily Times, 22 Oct 2003)..$^{5}$

On the other hand, it is often difficult for Māori male academics to relate to other Māori and especially other Māori men. I have found many Māori men to be contemptuous of academe, buying into the hegemonic notion that tanne should demonstrate their masculinity through physical pursuits such as manual labor and sports. Often I have faced ridicule from other Māori men because of what they perceive as my inabilities in practical and manual matters. In a sense, my uncallused hands demonstrate a lack of masculinity. ${ }^{6}$ Understandably, many tāne resist higher education because they see it as tantamount to assimilation into Pākehā values and attitudes. The monocultural nature of mainstream education in New Zealand means that Māori who succeed educationally are often viewed by other Māori as inauthentic or "plastic." Thus, I have found it almost impossible to discuss with other Māori men the theory and critical notions that underpin my work, because the language I speak is viewed as a Pākehā language, and the higher level of theoretical thought involved contrasts with the silent, tough, and practical Māori masculinity that is distortedly common. In many Māori contexts, to talk of theory is perceived as whakahīhi (conceited).

I have described some of my story here because I believe, as will become apparent, that the limitations I placed on myself, and others have placed on me, are genealogical constructions. However, this is not to say that all Māori men adhere to these constructions, for increasingly they do not; 
the reality is varied and complex. Yet it is also true that the dominant discourse, through many institutions, pervasively limits Māori men, and many Māori men swallow these constructions, affirming Michel Foucault's conception of the power/knowledge nexus. Such is the power of the dominant discourse-to create the reality it represents. As Edward Said argued, colonialism "can create not only knowledge but also the very reality [it] appear[s] to describe" ( 1978,94$)$.

The primary aim of this paper, then, is to deconstruct one of the dominant discourses surrounding Māori men-a discourse that was constructed to limit, homogenize, and reproduce an acceptable and imagined Māori masculinity, and that has also gained hegemonic consent from many tāne. I outline and focus on those historical racist notions of Māori masculine physicality that have developed into a contemporary portrayal-the natural Māori sportsman. To problematize this construction it is necessary to examine the racially based traits, such as physicality, imposed on tane in the precolonial and early colonial periods, and the role New Zealand state education has played in perpetuating this construction. I describe sport as a site of "positive" racism that acts as a contemporary conduit to channel tāne into the physical realm.

\section{Other Representations of MĀori Men}

From the outset it should be made clear that this paper provides analysis of only one of the numerous representations of Māori men that challenge the dominant discourse but typically lie outside the mainstream focus. Colonialism requires a limited system of representation or "regime of truth" concerning minority groups (Bhabha 1994, 7I), because allowing them self-determined individuality would undermine justifications for colonial rule: "The object of colonial discourse is to construe the colonized as a population of degenerate types on the basis of racial origin, in order to justify conquest and to establish systems of administration and instruction" (Bhabha I994, 70).

An example of a "regime of truth" displaying such "degenerate" typecasting is the supposedly inherent and savage violence of Māori men, which had to be curbed by the virtuous colonizers. I provide this example here to augment the upcoming discussion and to demonstrate that the "physical" Māori man prototype does not stand alone in the dominant discourse surrounding Māori men. In mainstream film and literature, the violence and physicality of tane has assumed an imagined reality. 
Important New Zealand films with significant Māori content such as Utu, Once Were Warriors, What Becomes of the Broken Hearted, and Crooked Earth recast the physically violent savage. Although the ${ }_{1983}$ film Utu is crammed with acts of Māori male violence, it was the slaying and beheading of a missionary by the central Māori male character, Te Wheke, that had a lasting impression on my image of the past savagery of Māori men because the setting was so close to home. While portrayed as merely a random act of savage revenge, the dramatization stemmed from a real-life event that occurred in my hometown. In I 865, Carl Volkner, the Anglican missionary and head of the Hiona Church (now known as St Stevens Church) in Ōpōtiki, was killed and his eyes eaten by Kereopa Te Rau and his men. ${ }^{7}$ This was an act of revenge for Volkner's conspiracy with the colonial government in its war against Hauhauism, Māori rebellion in general, and tribal unification. Volkner had been serving as a spy ("the eyes") for Governor George Grey, "keeping him informed on Maori activities in his parish" (Walker 1990, I3I). ${ }^{8}$ Kereopa Te Rau had lost his family through a massacre at Rangiaowhia, ${ }^{9}$ where the British forces had set alight a church with all the townspeople inside; he blamed the multiple murder on missionary complicity with the British (Walker I990, I24). Consequently, he sought $u t u$ (revenge) on those Pākehā conspirators who, either inadvertently or directly, had contributed to the deaths of his $w h \bar{a}$ nau (family). While the film partly justifies Te Wheke's violence through an opening scene in which innocent women and children are slaughtered by British soldiers, Te Wheke's $u t u$ is not grounded in a rationale; he appears to seek revenge for revenge's sake, killing Pākehā arbitrarily; he is, therefore, savage. In reality, Kereopa Te Rau sought revenge for his family's murder only on those whom he saw as complicit or responsible; he also fought in a larger rebellion against Pākehā oppression. Interestingly, in the film, Te Wheke's brother Wiremu, who plays chess and speaks French, provides a contrasting image of acceptable colonized Māori masculinity-one approved of by the British.

Once Were Warriors and its sequel, What Becomes of the Broken Hearted (which were also highly successful novels), center on the sociopathic violence of Māori father Jake Heke and its effects on his immediate family. Once Were Warriors provides a bleak yet realistic description of the violence in urban Māori life, and some resolution to the violence (ie, a return to traditional cultural practices and rural settings). Unfortunately, as its title suggests, the film intimates that the inherent violence of tane was, in precolonial times, appropriate for a noble warrior culture but 
today has become a natural symptom of urban Māori dysfunction. The film's illustration of the innate Māori male violence is never more pointed than in the repetitive heralding of Jake's explosive violence by the eerie wailing of a purerehua (bullroarer) - the wailing implying the stirring of the inherent savage within. What Becomes of the Broken Hearted also affords some remedy to Jake's violence by returning him to the traditionally physical masculine task of pig hunting, through which he is able to "return to nature" and employ his violence in a socially acceptable setting. Thus, the supposedly intrinsic violence of Māori males is naturalized and sanctioned within acceptable, colonized roles. Similarly, in Crooked Earth, a character representing colonized Māori masculinity is pitted against one portraying an unassimilated Māori male desperado. The former is a cleancut ex-army officer who has "the support of his people"; the latter is a long-haired, frenzied, horse-riding, gun-wielding outcast who attempts to build an economic empire by growing and selling marijuana. Naturally, both characters are violent and physical, yet one, the hero, employs his physicality in the service of the colonial powers and is rewarded for his nobility, while the other, the antihero, uses his physicality to oppose colonial law, and ultimately becomes a failed and embittered figure.

Films such as the three mentioned here "take the violence of the Maori, real or imagined, seriously. The effect of this is to question the morality of Maori culture and society, more specifically Maori males, especially fathers and leaders" (Cleave I992, 27-28). Even in Keri Hulme's Booker Prize-winning novel The Bone People, which is complex, intelligent, and sensitive, it is the imagined inherent violence of the Māori male father character that provides the pivotal theme.

\section{Precolonial and Early Colonial Māori Masculine Physicality}

Men are not born with masculinity as part of their genetic makeup; rather it is something into which they are acculturated and which is composed of social codes of behavior.

John Beynon, Masculinities and Culture

Māori masculinity cannot be analyzed merely from a contemporary snapshot; masculinity is a historical construction. In the nineteenth century, fictional and scientific discourses combined to produce the notion of the Māori race as Other (see Hokowhitu 2002, I-35; Smith I999, I9-4I). 
The mentality of "normalization," inherent in the fabric of European society at that time (see Foucault I972), meant that the colonists perceived themselves as superior and normal and consequently discounted Māori and tikanga Māori (Māori culture) as inferior and abnormal. Missionaries, for example, with little propensity to understand the complexities of Māori culture, simply described practices as barbaric (see Simon I990, 67-73; Smith I999, 78-79; Hokowhitu 2002, 36-67). Whether intentionally or not, early European travelers and missionaries sowed the seeds of a genealogy of representations in which Māori and tikanga Māori were depicted as inherently inferior (Hokowhitu 2002, 36-67; Smith I999, I9-4I). Representations of tāne, especially, had crystallized in the minds of colonizers even prior to their arrival. 10 "New migrants set off for their own adventures in the colonies armed with all their newly acquired misinformation" (Smith I999, 82).

Dominant racist representations of Māori men grew out of this mentality that cast the Pākehā man as normal and the Māori man as abnormal. ${ }^{11}$ Negative representations of tane centered on their not having attained the refined sensibilities of European men. While "civilized white men were the most manly ever evolved-firm of character; self-controlled; protectors of women and children" (Bederman I995, 25), Māori men were physical, whimsical, unsophisticated, childlike, ruled by passion-and therefore in need of enlightenment through civilization. As Gail Bederman suggested, "civilization wove [power, race, and gender] together by rooting them in a progressive, millennial tale of human history" (I995, 2I 7). This underscored the white man's humanistic "burden" to conquer the world, civilize it, and then provide enlightened leadership into the future. It was believed that only the white man possessed the mental fortitude to tackle such a burden; he was free to exercise his own will, virtuous, secular, liberated in thought, and autonomous. Conversely, the Other-the savage man-was represented as encumbered by his inability to evolve, ruled by his passions, physical, immoral, and sinful (see Bederman 1995; Hokowhitu in press).

At times, however, tāne were depicted as having seemingly positive qualities, such as "physical prowess," "nobility," and a "warrior-like nature" (Hokowhitu 2002, 47-52). Indeed, Māori were often referred to as the most civilized of all savages, or as historian Jock Phillips put it, the "Aryan Maori," a concept suggesting Māori, of all the indigenous peoples, "were most like us" (quoted in Schick and Dolan I999, 56). Regardless of whether the initial depictions of Māori masculinity were presented in 
a positive or negative light, the ensuing genealogy of representation these images created has served to limit tane access to the privileges enjoyed by Pàkehā men. The core of this paper discusses two related images that stemmed from the general "physical savage" discourse: tāne as naturally physical and practical-minded, and tāne as naturally athletic.

\section{The “Physical” Education of Māori Men \\ Tāne as Unenlightened}

Because tāne were supposedly ruled by passion as opposed to reason, those who subscribed to the philosophy of Cartesian dualism located them squarely within the physical domain. This categorization also corresponded with the representation of tane as savage, emotionally impulsive, aggressive, and violent (Hokowhitu 2002, I-67; Smith I999, I9-4I; Wall I997, 40-44). Cartesian reasoning added impetus to the universal civilizing mission, on the grounds that colonization would "enable humans to dominate, mature and create moral and just societies" (Best and Kellner 1997, 39). Consequently, the Others to be saved were represented as living in pre-philosophical dream worlds. According to Ernesto Laclau, the colonized peoples were considered to be essentially history-less and incapable of universal thought (1990, 67). Indigenous mythology circulated in the West was described as "irrational fairytales produced by unconscious history, meant for savages" (Nandy r983, 60). George Hegel suggested that primitives generically possessed a "character of spirit in a state of dream," as incapable of action, and therefore "pre-historical" (1956, 204-225).

Accordingly, Māori were represented as an intellectually inferior race. Māori reasoning was often described as closer to that of the ape than to that of the civilized European. Early settler Edward Wakefield believed the Māori passion for storytelling had all the sensibility of a primate: "Nothing can remind one more forcibly of the monkey who has seen the world, than a Maori thus relating news" (quoted in Best 1976, I20). Mid-nineteenth-century traveler Arthur Thomson, in his Story of New Zealand: Past and Present, Savage and Civilized, employed craniometry to quantify Māori intellect: "It was ascertained by weighing the quantity of millet seed skulls contained ... that New Zealanders heads are smaller than the heads of Englishmen, consequently the New Zealanders are inferior to the English in mental capacity... . The memory they possess is the memory of boyhood; and their minds may be compared to mirrors ... incapable of 
retaining any trace of the past.... The faculty of imagination is not strongly developed among them, although they permitted it to run wild in believing absurd superstitions. . . This analysis shows that the New Zealanders have the minds of children" (I 859, 8I-84).

\section{Tāne as Practical-minded and Physical}

The early representations of Māori men as unintelligent later mutated to "practical-minded" as colonizers realized the need for a manual workforce to create a South Seas rural paradise. ${ }^{12}$ The state education of Māori boys began to demand a corresponding emphasis on manual, technical, and agriculture skills. From the I 860 s through the I940s, educational policies reflected "a narrow and limited view of Maori potential and the role of Maoris [sic] in New Zealand society" (Barrington I988, 45). Māori boys received a limited form of education that channeled them into nonacademic areas, preventing them from gaining intellectual qualifications and subsequent white-collar employment.

In the mid-nineteenth century, the achievements of students in math, science, and literature at Te Aute College (a Māori boy's boarding school) were equal to any in the country, with the school producing scholars such as Sir Apirana Ngata and Te Rangi Hiroa (Peter Buck). In I 866, Inspector of Native Schools James Pope complained about this academic achievement, suggesting Te Aute should instead be an institute where "Maori boys could be taught agriculture, market gardening, stock farming, poultry keeping and bacon curing; and yet all the resources of the estate were being diverted to literary work" (Barrington I988, 47). As a result, Inspector General of Schools George Hogben asked school authorities to drop many of the academic subjects from the Te Aute curriculum. The outcomes of this event had "significant implications" for the future of tane (Barrington 1988, 47).

In 1906, Inspector of Native Schools William Bird declared that Māori were unsuited to academic subjects and unable to compete with Europeans in trades and commerce: "The natural genius of the Maori in the direction of manual skills and his natural interest in the concrete, would appear to furnish the earliest key to the development of his intelligence" (Simon I990, 98). In I9I0, the Reverend Butterfield, the headmaster of another Māori boys boarding school, told the Young Māori Party that "999 out of I000" Māori boys "could not bear the strain of higher education. In commerce Maori could not hope to compete with the Pakeha. In the trades the Maoris were splendid copyists, but not originators. As 
carpenters they would cope under a capable supervisor but not otherwise. Agriculture was the one calling suitable for Maoris . . . it was therefore necessary to teach them the 'nobility of labour'" (Barrington I988, 49).

The rhetoric became the reality by I9I3: "In none of the secondary Maori schools is there any attempt or desire to give what is usually understood by a 'college' education. ... The boys school in English and manual training-woodwork, elementary practical agriculture and kindred subjects and that is all" (Barrington I988, 53). Thomas Strong, the director of education from the late I920s to the mid-I930s, had a philosophy about the purpose of Māori education that was similar to that of his predecessors: "to lead the Maori lad to be a good farmer and the Maori girl to be a good farmer's wife" (Harker and McConnochie 1985, 95).

Unlike Pākehā men, who enjoyed a normal spread throughout occupational strata, by 1965, "nearly 90 percent of Maori men [were] employed as farmers, foresters, laborers, transport operators, factory workers, or in other skilled and unskilled occupations" (Watson 1967, 6). Confinement to manual labor, combined with a general discourse that described tāne as inherently physical, led to generations of tane thinking of themselves as "practical-minded" and unable to relate to abstract thinking. From the I960s to the I980s, tâne were further limited to blue-collar employment through educational streaming, contrived by normative intelligence tests that were based on the cultural capital of Pākehā (Simon I990; Hokowhitu 2002). The "failure" of Māori boys within state education has led many New Zealanders to view the overwhelming success of tāne in sport as a positive balance to this underachievement. ${ }^{13} \mathrm{I}$, on the other hand, believe the skewed success of tane in sport has become a form of positive racism. The following section deals historically and sociologically with the issue of Māori men and sport.

\section{TĀne as Natural Sportsmen}

The stereotype of the Māori as natural sportsman is derived from the "noble savage" ideal. A significant minority of Enlightenment commentators, such as Jean-Jacques Rousseau, believed that such savages enjoyed innocent moral superiority because they lived closer to nature (Miles I989, 24, 28). Many early travelers romanticized the savage Other as part of a natural physical world filled with "innocence and purity," as opposed to the "corruption and decay" of modern Europe (Smith I999, 49). The noble savage, in instances of extraordinary athleticism, was imagined to 
represent a naïve and mystical life prior to the reasoned life imbued by the scientific revolution. A late nineteenth century traveler to New Zealand, for example, related an invigorating tale of a "bronzed Maori man" competing in a primordial battle against nature: "The canoe was now rushing through the tide ... its expert helmsman, as rigid as one cast in bronze. ... The most lasting impression made ... was that of the poise and skill of Te Rangi Tuataka Takere, the high born Rangatira, as he sat statue like, steering-paddle firmly grasped, his fine muscular figure and clean cut tattooed features, reproducing, with the general surroundings, a grand picture of pure Maoridom as it had been for centuries prior to AD I 884. Alas! That we were to witness such a scene never again." (Skinner $1923,35-37$ )

The myth of the natural athleticism of Māori men has been actuated through tāne achieving in sport more than in any other area of societyso much so that sport has come to be viewed as a "traditional" characteristic of Māori masculinity. Ironically, many aspects of Māori masculinity now regarded as traditional were merely selected qualities of British colonial masculinity. In the hope of saving their people from near extinction, many tāne were forced to assume those masculine qualities that would abet their integration into the dominant Pākehā culture (see Walker I990). The consumption of Pākehā masculinity by tāne served to assimilate them into the violent, physical, stoical, rugged, and sports-oriented mainstream masculine world that has pervaded New Zealand society for most of its colonial history (Phillips 1987).

Yet this assimilation did not include indoctrination into the full gamut of colonial masculinities. The Māori male, like various "Othered" groups, had limited, conditional access to the white man's world. For example, as warriors in the service of the British army or in rugby: "They showed themselves to be good at those things which Pakeha men [were also] proud of. Maori were good at war and they were damn good at playing rugby, so they took on a special status of being Kiwi males with a slightly exotic flavour" (interview with Jock Phillips, quoted in Schick and Dolan I999, 56). However, tāne were only allowed access to arenas in which their success did not contradict the representational genealogy of the physical warrior that pervaded the New Zealand social narrative: "Maori, by their savage nature, were supposed to fight-in war or its peacetime substitute, rugby football. Neither required intellect" (MacLean I999, 2I).

For a culture on the brink of extinction and subjected to explicit racism in nearly all walks of society, sport offered tāne a sort of salvation. Fur- 
thermore, given the national hysteria for rugby throughout the twentieth century and the consequent status of the game, it is not surprising that, for Māori men, the rugby and rugby league field was a site where they could gain their community's respect and thus mana. One need only look at the obituaries in Mana Magazine to recognize that tāne are eulogized for their sporting feats. ${ }^{14}$ Similarly, the whaikorrero (speeches) heard at tangihanga (funerals) for tāne of my father's era typically lauded sporting success. When I heard my own father praised in this fashion at his tangihanga, I felt disappointment that his ability to play sport was privileged over his achievements as a creative and compassionate schoolteacher for forty years.

The success of tane in sport served three functions for the dominant group. First, it ingratiated tāne to a Pākehā public who had largely become antagonistic toward Māori following the civil wars of the I86os. However, by the end of the nineteenth century, Pākehā had come to the realization that Māori as a people were not going to die their predicted "natural death," 15 and, thus, they had to come to terms with their Māori neighbors. Sport was one of the obvious areas in which Māori men could gain public recognition without challenging the dominant discourse. Second, sport perpetuated stereotypes of Māori male savagery. Indeed, the I 888-89 "Native Team," the first national New Zealand rugby team to tour Britain, were depicted by the British press as a circus sideshowsavages from the South Seas (see Ryan 1993 for further discussion). Third, the existence of the Māori sportsman provided evidence that New Zealand's colonial system had enlightened and assimilated its savages. Rugby and cricket, "famously described as 'Britain's gift to the World,' marked out the contours of Empire. Sport became seen as essential preparation both for character and service in Empire" (Beynon 2002, 42). Māori sportsmen, in particular, were the greatest trophies of colonization because they signified assimilation and the success of British imperialization. ${ }^{16}$ The Māori sportsman was the disciplined brute, with his aggression and savagery confined to the sporting arena. Indeed, New Zealanders felt that the actions of the I 888-89 Native Rugby Team could credit or discredit the colonizing faculties of Britain's most recent conquest (Ryan I993, 3I-42). It was with satisfaction they read the newspaper judgments of their colonizing successes: The Daily Telegraph (London) reported, "The Maoris have certainly progressed since Captain James Cook . . . found the finely painted and neatly tattooed ancestors of our visitors eating each other in the bush" (quoted in Ryan I993, 44-45), while the Times 
(London) offered: "It is a tribute to our colonizing faculty. The colonizing race that can imbue the aboriginal inhabitants of the colonized countries with a love for its national games. ... Wherever the Englishman goes he carries the bat and the goal posts" (quoted in Ryan I993, 50).

\section{A Question of Evolutionary Scale and Genetics}

The success of Māori sportsmen in the twentieth century forced many Pākehā endeavoring to hold their position of racial superiority to represent that success as a matter of evolutionary scale and natural, animalistic brutality. According to this discourse, Māori sportsmen achieved as they did because they had yet to completely evolve out of the physical realm of the animal world. Gordon Slatter described the great Māori and All Black flanker Waka Nathan as a sleek, animal-like predator, with a "great instinct" and "great natural ability" embodied in a "splendid physique," his "dark rippling muscles" and "lithe speed" earning him the nickname of the "Black Panther" ( $1970,83-84) \cdot{ }^{17}$ Such a construction, while overtly positive, is implicitly linked to the nineteenth-century discourse of the soulless animal, which stemmed from the Cartesian claim that civilized reason had to be impartial and thus separate from the passions of the body (for more on evolution, race, and sport, see Hoberman 1997).

In a sense, Māori sportsmen, like other sportspeople of color, abet the dominant metanarrative by providing examples of the dominant regime of truth. Dave Andrews argued that Michael Jordan, for example, embodied "Reaganite American virtue" (I996, I38), and served as living proof of "an open class structure, racial tolerance, economic mobility, the sanctity of individualism, and the availability of the American dream for black Americans" (Gray 1989, 376, quoted in Andrews I996, I38). In a neoracist age, the overriding tenets of positivist discourse are egalitarianism, democracy, and social equality - the predetermined conclusions of an advanced and civilized western world. The successful Māori sportsman, then, acts as an exemplar of a subject in an egalitarian state who has triumphed over adversity to succeed; combine this with the common notion that sport reflects society, and the essential suggestion is that Mãori men are afforded equal opportunities in all walks of life. Insidiously, the Māori sportsman image can conversely be employed to imply that tane lack a work ethic and are lazy and fickle.

In contrast to Pākehā sportsmen, whose achievements are attributed to human endeavor, Māori men are said to achieve through innate physical 
attributes, and thus their achievements lack moral integrity. Such a view is clearly evident in this commentary by New Zealand's most celebrated sports broadcaster, Murray Deaker: "I think it is fantastic that we have this wonderfully athletic group of people that can help us develop our sport. . . . But I also want the hard, tough white farmer to be a part of my All Black side ... [The type of player who is] there for 80 minutes in a ruthless uncompromising way" (quoted in Matheson 200I, 32). Similarly, Auckland club rugby coach Dale Atken suggested that "the Polynesian boys are athletically explosive and that's paralleled [by] their concentration as well. When you make the comparison with the white guys, well they are 80-minute toilers. They are the workers" (quoted in Matheson 200I, 32). In these examples, Pākehā fortitude is credited as the primary engine of New Zealand's economic and cultural development. Ironically, just as state education gave tāne only those physical skills necessary to provide labor on Pākehā lands, so too have Māori men only gotten credit for natural athleticism. As former All Black Grant Fox put it, "Polynesian players were naturally superior to us in talent, but a lot of them aren't there now because they didn't have the discipline... . They lacked the right kind of mental attitude. They'd just turn up and play" (quoted in Hyde I993, 67). Later, as a sports broadcaster, Fox elaborated on what he meant by "mental attitude" in his analysis of the merits of two seven-a-side rugby teams about to clash in a world series final: "So here we have it: Fiji's raw speed and power versus Australia's organization[al] skills” (Television New Zealand commentary, Io Feb 200I). In other words, if the Fijians succeeded, it was because they were inherently physical people, but if the predominantly white Australian team succeeded, they did so through intelligence and organization.

\section{Channeling MĀori Boys into Sport}

The racist notions in the previous section are increasingly becoming the dominant discourse in New Zealand, where the talents of Polynesian male athletes are seen as raw materials to be captured, brought under Pākehā control, and molded into a commodity. For example, Farah Palmer's 2000 doctoral study found that many high school teachers viewed physical education or sporting, or both, as the curricular areas where Māori would naturally excel. One teacher said that "there is a certain stereotype for Māori and Pākehā that you have to face up to. ... Māori are good at PE. ... [We need to] ensure that the structure of courses are shaped around 
their interests, such as sport, so there is a practical application they can relate to" (quoted in Palmer 2000, 275; emphasis added). Another teacher based her opinions of Māori on their sporting success: "I like the Māori students because they are good at sport and they are enthusiastic about their sport" (quoted in Palmer 2000, 276). For Māori and Polynesian boys, sport has become the proxy for the early twentieth century "practical-mindedness" construction that limited their fathers, grandfathers, and great-grandfathers to working as manual laborers in Pākehā businesses.

Initial indications suggest that many New Zealand high school sports academies act as contemporary educational conduits for Māori and Polynesian boys into a world where making it as a sports star is the only available option. ${ }^{18}$ Although research in this area is in its infancy, some anecdotal evidence suggests that Polynesian boys are heavily overrepresented in high school sports academies, and that many of these offer little academic merit (Tristram 2002). From a purely personal perspective, I perceive that many of these so-called "academies" were initiated by individual high schools to relocate "trouble" students out of mainstream classes, for the sole benefit of "academic" students. These academies are viewed as educational sites that "suit" the "natural practicality" of Māori and Polynesian boys, and as places where they can be groomed for professional sporting careers. A cynic would suggest that they have merely been created to validate "nonacademic" students remaining at school, that is, to keep their errant students off the "dole queue" for another year or two, but also, and more importantly, to bolster the schools' sports teams.

New Right educational policies in New Zealand have meant that, like colleges in the United States, schools compete with each other to attract students. The chief marketing tools for many New Zealand high schools are their sports teams, and especially their rugby teams. Top boys schools employ talent scouts to strengthen their premier rugby teams in the hope of bolstering their schools' image and reputation through success in sports. Not surprisingly, they often target large Māori and Polynesian boys (Davis I999). Yet, the mainstream discourse recognizes this phenomenon as an acceptable alternative to providing Polynesian boys with an education system that caters to their academic needs: "The young Polynesian has become conscious of the fact that professional rugby can offer young Pacific Islanders and their families hope of a better lifestyle ... [it] is reminiscent of the way young black Americans got themselves out of the ghetto" (Matheson 200I, 24).

Unfortunately, Māori and other Polynesians also recognize sports as one 
of the few areas in which their boys can succeed in a larger system contrived to elicit their immanent failure: "A lot of the schools which Polynesians attend aren't up to meeting [their] needs . . . many of them are destined for failure without direction. But the young ones ... are learning that sports and rugby, in particular, offers a way for them to achieve" (interview with community leader Mapua Strickson-Pua, quoted in Matheson 200I, 24). Increasingly, Māori and Polynesian boys are compelled into "attempts at making it through athletic participation, rather than through the pursuit of other occupations that hold greater potential for meeting the real political needs of both themselves and their people" (Edwards I976, I67).

\section{The Māori Sportsman as Spectacle, and Sport as “Traditional” MĀori Masculinity}

Linked to the above discussion is the Māori sportsman as spectacle; an exemplar that reinforces Māori boys' aspirations to make it in the sports arena. Lynne Star suggested that rugby provides "scraps of positive Maori images that Maori are starving for," that is, images of "prestige and upward mobility in a Pakeha world" (I992, I34-I35). Yet, if the only positive Māori masculine role models Māori boys are exposed to in mainstream discourses are those of sportsmen, then they will continue to define success in terms of the physical-reinventing the power relationship between the intelligent/civilized colonizer and the inherently physical/savage colonized. The Māori sportsman thus represents "that part of the past that is still operative in the present" (Niranjana I992, 37). The spectacle of the Māori sportsman is dangerous not because it falsely represents reality but because it is "an arrested, fixated form of representation that, in denying the play of difference, constitutes a problem" (Bhabha 1983,27 ).

It is this fixated form of representation that is of most concern. As stated earlier, the constant alignment of tane with sport in the dominant discourse has occurred to such an extent that playing sport has come to be viewed as a "traditional" characteristic of Māori masculinity. Consequently, the dominant discourse invariably links symbols of "traditional" Māori masculine culture with sport, and especially with the physical and violent sports such as rugby union and league. The New Zealand rugby league team, which plays in the Australia-based National Rugby League 
competition, predominantly consists of Māori and Pacific Island players and is accordingly named the New Zealand Warriors. The team's "traditional" motif-a whakairo upoko (carved head with protruding tongue) - echoes the Warriors' name. The Waikato Super I 2 rugby franchise (located in the heavily Māori populated areas of Waikato and Bay of Plenty) is suitably named the Waikato Chiefs, while their motif features a hand clasping a traditional patu (club-like weapon). ${ }^{19}$

The taking over of All Black sponsorship by Adidas, the global sports clothing company, signified a wave of mass marketing based on selling the exoticism of traditional Māori masculine culture. Prior to the 1999 Rugby World Cup, mass billboards appeared in sites such as London's Trafalgar Square displaying the head of an ominous-looking Māori man with full traditional moko (facial tattoos). Simultaneously, Adidas unleashed a dramatized version of the All Blacks traditional performance of the "Ka Mate" haka, ${ }^{20}$ juxtaposing a montage of live footage of the then current All Black players performing "Ka Mate" with a ferocious traditional Māori warrior with full facial moko, dressed in only a piupiu (grass skirt), holding a taiaha (close-quarters combat weapon), against a backdrop of bubbling mud pools. This advertisement functions as a form of pastiche in the creation of a myth. That is, it takes two dissimilar concepts (ie, a present-day sport dramatization performed by a group of contemporary sportsmen, and the performance of a traditional Māori haka by a "traditional warrior" of precolonial times) and selectively overemphasizes their similarities to produce a myth-that sport is synonymous with traditional Māori masculine culture (Jameson I991, I6-I9).

Over time, constant alignment of, in this instance, Māori masculine icons with sport creates what Foucault and other poststructuralists consider an "exhibitionary regime of truth." The more the Māori male recognizes themselves and their supposed "traditional" culture in dominant images, "the less [they] understand [their] own existence and [their] own desires ... [their] own gestures are no longer [theirs] but those of another who represents them" (Debord 1970, 30, quoted in Best and Kellner 1997, 90). Indeed, Palmer found that Māori students were adhering to physical representations of themselves, such as "good with their hands" and "practical," and thus "it was not surprising that many of the participants had career aspirations in sport" $(2000,278)$. It is with sadness and anger, then, that I watch Māori and other Polynesian students being awarded only sports trophies at my own sons' school assemblies. 


\section{Conclusion: TALKing BaCk}

The most striking image of Māori men I have seen is a late-eighteenth or early-nineteenth-century photograph of a group of tāne and children outside a whare (house). Some of the tāne have their arms around each other, while others cuddle their children or casually laze on each other in open displays of friendship and caring. The image is so arresting because of its stark contrast with the dominant portrayal of tanne as inherently physical, staunch, hypermasculine, and violent. Instead, this photo suggests that tāne stem from a loving and caring culture. The photo takes on a darker hue when viewed against the context of the violent turmoil of colonization, which has caused the cultural violation of Māori masculinity.

Increasingly, there are representations of Màori men that challenge the dominant discourse described in this article, but typically these images lie beyond the dominant gaze. Television programs such as Marae and Waka Huia, which are both telecast on the Sunday morning off-peak time slot on Television New Zealand, feature an abundance of articulate and intelligent tāne. The Don Selwyn-directed film The Māori Merchant of Venice displays an ensemble of Māori male actors who demonstrate the poetic, intelligent, and highly refined nature of Māori language and culture in a musically rich Shakespearian drama. Tāne in Shakespearian garb reciting verse in the Māori language provide a stunning contrast to the musclebound Jake Heke model. In literature, although there is a notable dearth of Māori male characters that challenge the violent and physical stereotypes, there are some exceptions. In Witi Ihimaera's work, a common theme of exploring the conflict between traditional and transforming gendered roles and sexuality allows for complex and diverse Māori male characters. In his Nights in the Gardens of Spain (1995), a bisexual Māori male father (David) has to reconcile the differences between his two lives, as a husband, father, and academic on the one hand, and as man who enjoys the company of other men in "the Gardens of Spain" on the other. Similarly, in The Uncle's Story (2000), traditional Māori attitudes toward homosexuality and masculinity are explored as a Māori man (Michael) discloses his sexuality to his parents. Also, in Bulibasha (1994), Simeon is an educated rebel who deplores the violence of his overbearing father. Despite these characters, Ihimaera's "realism" means that many of his Māori male characters, especially traditionalists, leaders, and fathers, are prototypically violent, physical, and overbearing (eg, Tamihana in Bulibasha and Koro in The Whale Rider [1987]). The work of novelist, short- 
story writer, and children's author Patricia Grace is notable for the varied depictions of Māori people and their lives; the variation in itself undercuts stereotypical notions of Māori. For example, in Potiki (1986), Hemi Tamihana is sensitive, hardworking, patient, and wise.

Regardless of what images of tāne exist, and whether or not they bolster or challenge the colonial indoctrination of a physical masculine prototype, many tāne are able to live beyond such hypermasculine constraints. That is, the dominant image of Māori men often belies the reality of those tàne who exist outside such constructions. Indeed the multitude of tanne who contradict the caricature of Jake the Muss render such stereotypes farcical. ${ }^{21}$ Composers, writers, and filmmakers, such as Pei Te Hurinui Jones, Ralph Hotere, Selwyn Muru, Muru Walters, Paratene Matchitt, Witi Ihimaera, Hone Tuwhare, and Don Selwyn, along with intelligentsia such as John Rangihau, Hirini Melbourne, Ranginui Walker, Mason Durie, Hirini Moko Mead, Timoti Kāretu, and Graham Smith, problematize mainstream notions about tāne. Unfortunately, too few images of these inspirational men and the like are permitted visibility to the dominant gaze.

The unwillingness of the mainstream to engage with representations of Māori men who challenge its premises signifies that tàne themselves must recognize the fallaciousness of the dominant discourse and resist it by living beyond those constructs-for as Audre Lorde poignantly points out, "the master's tools will never dismantle the master's house" (I98I, 99; italics in original). And indeed, with the success of the educational movements Kohanga Reo (preschool total-immersion language nests) and Kura Kauapapa (primary and high schools based on tikanga Māori and total language immersion), Māori boys are learning that masculine Māori culture is not inherently staunch, physical, and violent. Màori boys and men who are steeped in their own culture realize the significance of whanaungatanga (family), hinengaro (intellect), wairua (spirituality), aroha (love and compassion), and manaakitanga (support and concern for others). It is through Māori men's own culture that they will find what it truly means to be a Māori man, freed of the dominant construct, and permeated instead with humility, intelligence, creativity, love, and compassion.

The focus of this paper has been to deconstruct some of the "truths" written into New Zealand's social narratives regarding Māori masculinity, in the hope of dislodging the authenticity and privilege of the dominant discourse. Such an analysis would not have been effective as a snapshot of a single image; rather, a genealogical treatment was required to explore 
the historical underpinnings of the image of the naturally physical Māori man. This representation began as a conscious attempt to subjugate the masculine Other by limiting him to the physical realm. Initially, tāne were forced into manual labor by confiscating their land and restricting their options through a racist state education system. In the neo-racist era, the representation has mutated to positively framed sporting images that serve a largely subconscious subjugation. Through this article I hope, as a Māori male, to insert my voice in opposition to the "truth" about physical Māori masculinity created by the dominant discourse.

* $* \quad *$

I WOULD LIKE TO THANK the two anonymous reviewers for their insightful comments, and Professor Vilsoni Hereniko and Professor Douglas Booth for their help with this paper.

\section{Notes}

I Māori is a generic word that initially meant "normal" but has come to represent (incorrectly) the tribal-based indigenous peoples of the Pacific Islands now called New Zealand. Mason Durie has this to say about being Māori: "Before European contact, the word Māori simply meant normal or usual. There was no concept of a Māori identity in the sense of cultural or even national similarities. ... The original inhabitants of New Zealand did not refer to themselves as Māori; rather they were Rangitāne or Ngāti Apa or Tūhoe or any of forty or more tribes" (I998a, 53).

Many writers use the phrase "Aotearoa/New Zealand" to depict the nation state. I refrain from employing "Aotearoa" because its use implies that there was or is such a thing as a Māori nation. The popularized use of Aotearoa symbolizes the idea of a united and contented people living under a "long white cloud."

The term tāne can refer to men, a man, a husband, or males in general, but in this context I employ it specifically to mean Māori men.

2 Pākehā is the common name for New Zealanders who identify predominantly with a European genealogy. Literally, Pākehā means foreign.

3 Ōpōtiki is a small, rural town in New Zealand's Bay of Plenty that services a vast geographical area, including several outlying Māori communities. Ōpōtiki's population of about 4,000 is approximately 70 percent Māori.

4 As opposed to the "ancestral-descendant" meaning of genealogy, I employ the term "genealogical" in this article in the Foucauldian sense, that is, to connote the "regime of truth" that survives in part via a connection to biologically and 
culturally racist historical vestiges. The term also suggests that bio-racist ideas (which lead to racism) have been constructed as being genealogically and biologically determined.

5 Dunedin is a city on the southeast coast of New Zealand, where the University of Otago is located.

6 I use the term "uncallused" here because of the famous whakatanki (proverb), "Marry a man with calluses on his hands."

7 Kereopa Te Rau was one of the leaders of the Hauhau, an anti-missionary yet religious "cult" that sought the political unification of tribes against their "common oppressor," the colonial government (Walker I990, I30).

8 Of note was the "unwarranted penalty of confiscation of 69,200 hectares of [Whakatohea] land" (Walker I990, I3I) as recompense for Volkner's death, regardless of the facts that the Whakatohea people, who are the local Ōpōtiki people, did not commit Volkner's murder, and that Kereopa Te Rau and a Whakatohea chief, Mokomoko, had been executed for the crime.

9 Rangiaowhia is located in the Waikato area (upper-central North Island).

IO I suggest "especially" here because, in transposing their European, malecentric worldview to the colonies, the early missionaries, travelers, and anthropologists assumed that Māori culture was also male hegemonic. For example, most missionaries, travelers, and anthropologists were only interested in the male perspective when investigating and describing cultural artifacts.

I I This is not to say that there was or is one general Pākehā masculinity. There were and are different Pākehā masculinities based on class, genealogy, and religion (eg, upper-class English Protestant immigrant versus lower-class Irish Catholic immigrant). However, as a tactic of power, Māori masculinity was employed to provide a counterpoint for the emerging dominant Pākehā masculinity.

I 2 "South Seas rural paradise" is a nomenclature common to colonial New Zealand culture, referring to the expatriate English coinage that symbolized the hope of a better life and society outside of the "motherland."

I 3 The word "failure" appears in quotation marks here to indicate my belief that rather than Māori having failed in the education system, the state education system has failed Māori.

I4 Mana Magazine is a glossy bimonthly, published in Papatoetoe, dedicated to Māori issues, events, and stories.

I 5 In the mid to late nineteenth century, according to the evolutionary "survival of the fittest" philosophy, it was commonly assumed that Māori would inevitably die out (Hokowhitu 2002). Māori extinction was considered an unfortunate but natural phenomenon: "Just as the Norwegian rat has displaced the Māori rat, as introduced plants have displaced native plants, so the white man will replace the Māori” (Durie I998b, 30).

I6 The assimilation into sport of Māori men, more than of Māori women, was an important indicator of the success of imperialization because, from the 
British perspective at least, the savage violence of tane posed a larger threat to Pākehā settlement.

I7 The All Blacks are New Zealand's national rugby team, renowned as the most successful sports team ever.

I 8 New Zealand high school sports academies are typically programs set up for senior school students (years I I to I3) to complete sports industry-based training, which can be separate or in conjunction with the standard state education curricula. However, state education has no mandated control over what is taught or what can be achieved through these programs; under New Right educational policies, high schools have become independent bodies that can operate outside government curricular control, especially in the senior school.

I9 Super I 2 is a professional rugby union competition contested by teams from New Zealand, South Africa, and Australia.

20 The All Blacks perform the "Ka Mate" haka written by the famous (and infamous) Ngāti Toa chief, Te Rauparaha, in the I82os. For further discussion of "Ka Mate" and the All Blacks, see Jackson and Hokowhitu 2002.

2I Jake the Muss is a pseudonym for Jake Heke, a hypermasculine (and especially violent) Māori character in the film Once Were Warriors.

\section{References}

Andrews, Dave

I996 The Fact(s) of Michael Jordan's Blackness: Excavating a Floating Racial Signifier. Sociology of Sport Journal I3:I25-1 58.

Barrington, John

I988 Learning the "Dignity of Labour": Secondary Education Policy for Maoris. New Zealand Journal of Educational Studies 23: 45-58.

Bederman, Gail

I995 Manliness and Civilization. A Cultural History of Gender and Race in the United States, I880-1917. Chicago: University of Chicago Press.

Best, Elsdon

I976 Games and Pastimes of the Maori. Wellington: Government Printer. Best, Steven, and Douglas Kellner 1997 The Postmodern Turn. New York: Guilford Press.

Beynon, John 2002 Masculinities and Culture. Buckingham, uk: Open University Press. Bhabha, Homi I983 The Other Question. Screen 24 (6): 27.

I994 The Location of Culture. New York: Routledge.

Cleave, Peter

I992 Revisiting the Warrior. Illusions I 8:27-3I. 
Davis, Stephen, director I999 Boot Dreams [videorecording]. Television New Zealand.

Debord, Guy I970 The Society of the Spectacle. Detroit: Black and Red.

Durie, Mason

I998a Te Mana, Te Kāwanatanga: The Politics of Māori Self-Determination. Auckland: Oxford University Press.

I998b Whaiora: Māori Health Development. 2nd ed. Auckland: Oxford University Press.

Edwards, Harry

I976 The Black Athletes: 2oth Century Gladiators for White America. In Sport Sociology: Contemporary Themes, edited by Andrew Yiannakis, I67-I80. Dubuque, IA: Kendall/Hunt Publishing Co.

Foucault, Michel

I972 The Archaeology of Knowledge. Translated by Alan Sheridan. London:

Tavistock.

Grace, Patricia

I986 Potiki. Auckland: Penguin.

Gray, H

I989 Television, Black Americans, and the American Dream. Critical Studies in Mass Communication 6:376-386.

Harker, Richard, and Keith McConnochie

I985 Education as Cultural Artifact: Studies in Maori and Aboriginal Education. Palmerston North, NZ: Dunmore Press.

Hegel, George

I956 The Philosophy of History. Translated by J Sibree. New York: Colonial Press.

Hoberman, John

I997 Darwin's Athletes: How Sport has Damaged Black America and Preserved the Myth of Race. New York: Mariner Books.

Hokowhitu, Brendan

2002 Te Mana Māori-Te Tātari ngā Korero Parau. PhD thesis, University of Otago, Dunedin.

2003 Māori Masculinity, Post-structuralism, and the Emerging Self. New Zealand Sociology I 8 (2): I79-20I.

Hulme, Keri

I983 The Bone People. Wellington, nz: Spiral

Hyde, Tom

I993 White Men Can't Jump: The Polynesianisation of Sport. Metro (Auckland) I 47 (Sept): 62-69.

Ihimaera, Witi

I987 The Whale Rider. Auckland: Heinemann. 
1994 Bulibasha: King of the Gypsies. Auckland: Penguin.

1995 Nights in the Gardens of Spain. Auckland: Secker \& Warburg.

2000 The Uncle's Story. Auckland: Penguin.

Jackson, Steve, and Brendan Hokowhitu

2002 Tribes and Technology: The New Zealand All Blacks Haka and the Politics of Identity. Journal of Sport and Social Issues 26 (2): I 25-I39.

Jameson, Fredrick

I99I Postmodernism, or, The Cultural Logic of Late Capitalism. London: Verso.

Laclau, Ernesto

1990 New Reflections on the Revolution of Our Time. Translated by Jon Barnes. New York: Verso.

Lorde, Audre

I98I The Master's Tools Will Never Dismantle the Master's House. Comments at "The Personal and the Political" panel, Second Sex Conference, October 29, 1979. Reproduced in The Bridge Called My Back: Writings by Radical Women of Color, edited by Cherríe Moraga and Gloria E Anzaldúa, 98-ıог. Watertown, мa: Persephone Press.

MacLean, Malcom

I999 Of Warriors and Blokes: The Problem of Maori Rugby for Pakeha Masculinity in New Zealand. In Making the Rugby World: Race, Gender, Commerce, edited by Timothy Chandler and John Nauright, I-26. London: Routledge.

Matheson, John

200I So What's the White Answer? NZ Rugby World 47:20-38.

Miles, Robert I989 Racism. London: Routledge.

Nandy, Ashis

I983 The Intimate Enemy. Oxford: Oxford University Press.

Niranjana, Tejaswini

1992 Sitting Translation: History, Post-structuralism, and the Colonial Context. Berkeley: University of California Press.

Palmer, Farah

2000 Maori Girls, Power, Physical Education, Sport, and Play: "Being HunPhillips, Jock gus, Hori, and Hoha." PhD thesis, University of Otago, Dunedin.

I987 A Man's Country? The Image of the Pakeha Male-A History. Auckland: Penguin Books.

Ryan, Greg

1993 Forerunners of the All Blacks: The I888-89 New Zealand Native Football Team in Britain, Australia and New Zealand. Christchurch: Canterbury University Press. 
Said, Edward

I978 Orientalism. New York: Vintage Books.

Schick, Ruth, and John Dolan

I999 Masculinity and A Man's Country in I998: An Interview with Jock Phillips. In Masculinities in Aotearoa/New Zealand, edited by Robin Law, Hugh Campbell, and John Dolan. Palmerston North, Nz: Dunmore Press.

Simon, Judith

I990 The Place of Schooling in Maori-Pakeha Relations. PhD thesis, University of Auckland, New Zealand.

Skinner, William

I923 Surf-riding by Canoe. Journal of the Polynesian Society 32:35-37.

Slatter, Gordon

I970 On the Ball: The Centennial Book of New Zealand Rugby. Christchurch, nz: Whitcombe \& Tombs.

Smith, Linda

I999 Decolonizing Methodologies: Research and Indigenous Peoples. Dunedin, NZ: University of Otago Press.

Star, Lynne

I992 Undying Love, Resisting Pleasures: Women Watch Telerugby. In Feminist Voices: Women's Studies Text for Aotearoa/New Zealand, edited by Rosemary Du Plessis, I 24-I40. Auckland: Oxford University Press.

Thomson, Arthur

I 859 The Story of New Zealand: Past and Present, Savage and Civilized. Vol I. London: John Murray.

Tristram, Kent

2002 The Structure, Design and Intent of Sport Academies in New Zealand Secondary Schools. Master's thesis, University of Otago, Dunedin.

Wakefield, Edward

I 845 Results of the New Zealand Inquiry. London: Spectator.

Walker, Ranginui

I990 Ka Whawhai Tonu Matou: Struggle Without End. Auckland: Penguin Books.

Wall, Melanie

I997 Stereotypical Constructions of the Maori "Race" in the Media. New Zealand Geographer 53:40-45.

Watson, John Elliot

I967 Horizons of Unknown Power: Some Issues of Maori Schooling. New Zealand Council for Educational Research. Wellington: New Zealand Government Printer. 


\section{Abstract}

The primary aim of this paper is to deconstruct one of the dominant discourses surrounding Māori men-a discourse that was constructed to limit, homogenize, and reproduce an acceptable and imagined Màori masculinity, and one that has also gained hegemonic consent from many tāne. I use a genealogical approach to outline the historical underpinnings of the image of the Māori man as naturally physical, and the mechanisms, including the confiscation of land and a racist state education system, that served to propound and perpetuate this construction. The contemporary portrayal of the natural Māori sportsman has evolved from these historical roots in what has become a largely subconscious but no less insidious pattern of subjugation through positively framed sporting images.

KEYWORDS: Māori, masculinity, sport 